Tanabayeva A., Alikbayeva M.B., Alibekuly A.

Al-Farabi's doctrin: virtuous people and a model of the «perfect man»

Танабаева А., А^икбаева М.Б., А^ибекулы А.

Ә^-Фараби концепциясы: қайырымды адамдар және «кемел адам" моделі

Танабаева А., Аликбаева М.Б., Алибекулы А.

\author{
Концепция аль-Фараби: \\ добродетельные мюди \\ и модель «совершенного \\ человека»
}

The first socio-political thinker among the Arabic philosophers, Al-Farabi expanded the boundaries of speculation prior to the consideration of human nature, the meaning of his life, his place in the universe, its role in society, the nature of the state association, expressing their dissatisfaction with the Islamic concept of man. In the era of universal domination of the religious worldview approach of blind faith led to the interpretation of the person is fundamentally different from the officially accepted. In contrast to the Islamic concept of a man as a creature among creatures and servant of God, Al-Farabi considered a man in several aspects of his life: as a physical being, as a living being, as the highest natural mixture, as a rational animal, as a civil creature.

Key words: Al-Farabi, virtuous city, perfect society, a perfect man, Arab-Muslim culture

Ә^-Фараби мұрасы әр уақытта да, қазіргі жаһандану кезеңінде де өзекті тақырып. Оның ғылыми еңбектеріне көптеген ғалымдардың қызғушылық танытуынан оның мұрасынан көптеген көкейтесті мәселелердің жауабын табары сөзсіз. Осыған орай кемел қоғам, қайырымды қала және кемел алам мәселесі ерекше қайталанбас $А ү-$ ние. Әл-Фараби мен оның ізбасарларының ілімдеріндегі кемел қоғам моделін тек Шығыста ғана емес, Батыста да үлкен қолданыста.

Аталған мақалада, қайырымды қала, мейірімді тұрғындар мен кемел адам мәселесінің маңыздылығы мен мәні қарастырылады және ислам мәдениетіндегі кемел аАам мәселесі бойынша алғашқы көзқарас тудырған сопылардың еңбектеріндегі кемел адам моделіне талАау жасалынады.

Түйін сөздер: әл-Фараби, қайырымды қала, кемел қоғам, кемел адам, араб-мұсылман мәдениеті.

Наследие А^ь-Фараби было и остается актуальным в современный век глобализации. Возрастающий научный интерес ученых всего мира объясняется тем, что мы находим ответы на многие проблемы и вопросы в трудах великого мыслителя. В этой связи его концепция совершенного общества, добродетельного города и совершенного человека уникальна. Учение А^ь-Фараби повлияло на творчество многих его последователей и стало основой развития модели совершенного общества не только на Востоке, но и на Западе.

В данной статье мы рассмотрели значение и важность добродетельного города, добродетельных жителей и совершенного человека в трудах А^ь-Фараби, также бы^ дан краткий анализ модели совершенного человека в трудах суфиев, которые впервые в исламской культуре подняли вопрос о совершенном человеке.

Ключевые слова: А^ь-Фараби, добродетельный город, совершенное общество, совершенный человек, арабо-мусульманская культура. 


\section{AL-FARABI'S DOCTRIN: VIRTUOUS PEOPLE AND A MODEL OF THE «PERFECT MAN»}

\author{
Within the framework of the project \\ "The cultural model of Kazakhstan in thirty developed countries: \\ problems of integration and intercultural \\ communication in a changing world»
}

On the basis of reasonable activity of a man as his natural properties Al-Farabi made a number of conclusions about the humanistic equality of all people as a result of the overall reasonable nature of the autonomy of the human being, the creative activity of the person, freedom of the human will, independent of the value of human life. This issue Al-Farabi considered in his «Treatise on the views of the residents of the virtuous city».

Perfect society of Al-Farabi divides into three types: the great, medium and small. Great Society - a collection of companies of all people living in the land, the average - an association of people in some parts of the land, small-a small association of residents.

The greatest good and the highest perfection can be achieved, according to al-Farabi, primarily the city, but not society, standing on the lower level of perfection. The latter Al-Farabi considers the village, district, street and house. This system is a perfect society, drawn by Al-Farabi with strict logical sequence is the result of logical thinking scientist coming from the relationship between the concepts of general and private.

So, the most perfect form of society, by Al-Farabi, is the city. He uses the term city not only represents the city in the modern sense, as a unit of administrative-territorial division, but also to refer to the state and social groups.

An important place in the social and ethical teachings of AlFarabi is the idea of a virtuous city. Virtue, according to Al-Farabi, - this is the best moral qualities.

Virtues of Al-Farabi shares on ethical and intellectual. For ethical virtues he reckons temperance, courage, generosity and justice, to the intellectual - wisdom, intelligence and wit.

So the most important points of ethics Al-Farabi: true happiness is the possession of all these virtues. Moreover, virtuous people he calls free in nature.

In connection with this interesting reflection of Al-Farabi on the division of people into three types depending on the judgment and 
temperament. The first type - people free in nature. They are reasonable and resolute. The second type - the people who do not have these two properties of Al-Farabi calls brutish. The third type - slaves by nature, they are reasonable, but do not have the determination. Truly happy are people free by nature, concludes Al-Farabi. Virtuous city of AlFarabi defines as «a city in which an association of people is aimed at mutual assistance in cases with which finds its true happiness». It is this cooperation to achieve true happiness virtuous city is different from all other human communities. Self-isolation and loneliness can not make a man happy. The basic principle of the virtuous city of Al-Farabi considered justice. Every citizen of this state justice devotes special session and the special situation. The dominance of justice in the virtuous city unites more diverse and heterogeneous parts of the state in whole.

Following Aristotle Al-Farabi considered possible existence of only one, but two-level (sublunary and superlunary) world, the eternal and dynamic existence of which is due to be inseparable from the world supersensible essence, Aristotle called the prime mover, Al-Farabi - the first cause. In contrast to the Platonic-Plotinian principle generated by the demiurge, or one world, Al-Farabi accepted the Aristotelian principle of eternal and not generated world. The task of philosophy he thought a description and explanation of existing forever and eternity of existence through a qualitative analysis of the various parts of the universe, a qualitative description of the processes in detail in it, understood as the actualization of potential though, but the existing one. Ethics in the modern sense of the category of «virtue» for Al-Farabi is the key to the teleological interpretation of being as the universe and human itself, and human in society, as a virtue is a way of thinking, knowledge. In fact, education is one of the most important social phenomena in AlFarabi's philosophical system. It is concerned with the human soul and makes sure that the individual is prepared from an early age to become a member of society, to achieve his own level of perfection, and thus to reach the goal for which he was created. However, while it is true that there are no writings specifically devoted to education in Al-Farabi's books, anyone who follows his writings with care will come upon various texts scattered here and there containing clear educational elements corresponding to his overall philosophical views, which incline to integrate separate concepts and thoughts into a 'unified world view'. Indeed, the whole activity of education, in Al-Farabi's view, can be summed up as the acquisition of values, knowledge and practical skills by the individual, within a particular period and a particular culture. The goal of education is to lead the individual to perfection since the human being was created for this purpose. The perfect human being (al-insan al-kamil), thought Al-Farabi, is the one who has obtained theoretical virtue - thus completing his intellectual knowledge-and has acquired practical moral virtues - thus becoming perfect in his moral behaviour. Then, crowning these theoretical and moral virtues with effective power, they are anchored in the souls of individual members of the community when they assume the responsibility of political leadership, thus becoming role models for other people. Al-Farabi united moral and aesthetic values: good is beautiful, and beauty is good; the beautiful is that which is valued by the intelligentsia [1]. So this perfection which he expects from education combines knowledge and virtuous behavior; it is happiness and goodness at one and the same time. Al-Farabi concerned not only personal, but also social perfection and his «virtuous city» (madina fadylya) built on principles borrowed primarily from Platonism, Neo-Platonic and Aristotelian although construction elements of his teaching can not be underestimated. The political philosophy of Al-Farabi had little to do with the political theory in the Arab-Muslim culture.

Virtuous city - this is the best state system has features of moral and political organizations that are able to provide state solution to any problems. Virtuous city is based on the hierarchy. Hierarchy involves not only the relations of domination and subordination, but also harmony and balance. This is expressed in the Muslim world view in terms of socio-political system, which is inherent in all traditional societies.

In addition, the hierarchy of the virtuous city reflects the objective space order, which is a reflection of the reality of the earth in order. AlFarabi believed that earthly life should reflect the wonderful harmony of the cosmos, as the laws of social development related to the eternal laws of existence. According to Al-Farabi, not knowing the mysteries of world harmony, it is impossible to build a perfect society.

With regard to the occupation of the inhabitants of the virtuous city, every man in it should do one specific thing for life

Virtuous city of Al-Farabi opposed non-virtuous city, of which there are three types of «ignorant city», «wicked city», «city misguided».

In the ignorant people of the city, according to Al-Farabi, had no idea of the true happiness and do 
not know the ways to achieve it. Of all the benefits of city residents are aware of the ignorant ones that are only apparently benefits. Such bodily health, wealth, pleasure, freedom to indulge the passions, honor and majesty. Each of these benefits seem ignorant inhabitants of the city of happiness, and the greatest happiness they believe a combination of all of these benefits. Accordingly misfortune they believe the body of disease, poverty, lack of pleasure, the inability to follow their passions and lack of honor.

Subspecies «ignorant of the city» are «necessary city», «city exchange», «city meanness», «city of ambition», «power-hungry city», «voluptuous city».

The basis for the division of society into «virtuous» and «ignorant» of Al-Farabi considered the objectives pursued by these companies. Correct the goal contributes to happiness. In this case, AlFarabi stated that the right to be not only a goal, but also how to achieve it. The best - it's nice to reach the goal and dignity.

It is clear that the description of the «ignorant» of cities - a kind of protest against Al-Farabi the social system of the era. In various types of ignorant cities expressed vices peculiar to the society of his time: ignorance, greed, lust for power, idle life.

Imam -the head of the virtuous city, according to Al-Farabi, should have specific congenital and acquired qualities. In this it differs from other members of the city.

Speaking about twelve congenital as head AlFarabi repeated ideas of Plato. Al-Farabi believed that just as the organs of the body differ in their nature and abilities, just as members of the city and the union differ. And if in the body of the hierarchy of ends authorities, which do not run, but only subject to, the state hierarchy ends class whose sole responsibility is to obey and execute orders.

Chapter virtuous city of Al-Farabi compared with heart, the main organ of the human body. The heart is the cause of the existence and location of certain other organs of the body. If you come to upset any of the bodies, the life of the whole body will not stop, but if you «fail» the heart, the person dies.

Understanding of man as a spiritual and bodily unity Al- Farabi set out from this point of view, the theory of the perfect man. This harmonious development of personality, combining physical and mental qualities: healthy body, a clear mind, imagination, a good memory, wit, expressive speech, curiosity, intelligence in sensual pleasures, love of truth, nobility of soul, contempt for wealth and others. Especially, Al- Farabi considered necessary the presence of the quality of justice in the perfect man, who must «love ... justice and its advocates, hate injustice and tyranny of those from whom they come; to be fair to her and to others, to encourage justice and indemnify the victims of injustice ... to be fair, but not stubborn, do not be capricious and not to persist in the face of justice, but to be quite adamant to every injustice and meanness ... «[2]. Man combines all these qualities, worthy to be a ruler. Moreover, such a person is required to society as head of the city.

Ideal of the perfect man at Al-Farabi coincided with the ideal head of state because the only perfect man can entrust the fate of people: one who is intelligent, can teach people how to reason, one who is virtuous, educates people virtuous, one who is happy, can make people happy. Al-Farabi stated that a person standing on the highest perfection, combines quality must meet not only the true philosopher, the governor and the legislature, and, but the imam.

The perfect man in Al- Farabi is a person giving their all for the benefit of society and will find happiness in serving the public interest.

The concept of the mind is the basis of the theory of knowledge of Al-Farabi, because of it created the preconditions for the development of epistemology in the eastern peripatetism. At AlKindi these frameworks have been limited because it recognized the priority of divine revelation. For Al-Farabi same priority rational knowledge is undeniable. It is very important and that he prefaced his perceptual knowledge as inferior, but necessary step. Recognition of the primacy of feelings in understanding the world and leads to the appropriate interpretation of rational knowledge: performing an integrative role, it is closer to the earth than to heaven, the world. To achieve the ultimate goal of rational knowledge - get the truth involved logical operations. All those operations that are entirely dependent on the person. The foregoing suggests that Al-Farabi played a progressive role in the development of the theory of knowledge on the Arabic-speaking East.

In the theory of knowledge of Al-Farabi clearly outlined materialistic and idealistic tendencies: on the one hand, man appears as the owner of creativity, which leads him to the knowledge of the world, on the other hand, the source and destination knowledge are the first cause of all things.

A major role in cognition play feeling, because they represent the starting point of understanding the world, which results in abstractions or concepts, detachment from matter, and, superimposed on the 
individual items, they concretize them and unite in the genera and species.

Vividly process of knowledge of Al-Farabi described in his treatise "On the pursuit of happiness». Here, as in many other treatises, the acquisition of knowledge is identified with the achievement of happiness. Since the pursuit of happiness is the goal of human life, then it follows that it is carried out through the knowledge of a man of the world and ethical norms to guide his life [3].

Development problems of improving the human has been developed not only within the framework of the Arab medieval philosophical and also religious thought.

Insan Kamil in Sufism ideal of the perfect man, who won a nafs and reached the state khakik. This category was developed by Arab philosopher Ibn Arabi. Unlike modern European ideas, al-Insan alKamil is not a crown of evolution as perfect people in the form of saints were in ancient times. From the point of view of Ibn Arabi is a perfect man was Prophet Muhammad. This is the perfect man who is the embodiment and manifestation of the divine attributes. This term was introduced by Hallaj, who was executed for his beliefs in the 309/921 year. After him, this idea was developed by Ibn Arabi (d. 638/1240). The doctrine of the «perfect man» is primarily ontological problem and is associated with the problem of existence. According to Ibn Arabi, the world was originally soulless. A man became a manifestation of all the divine attributes and perfect names.Sufism has no canonical text. Sufis themselves to describe the essence of his cult use a variety of terms. They call it the science of Sufism, the art, the religion. Considering Sufism in terms of the problem of improving a person on the basis of religion and science, it should be noted that in the most general sense, Sufism is interpreted by the Sufis as the necessary experience of being, the purpose of improvement of man, which is achieved through the discovery and awakening in man the supreme body of the implementation, completion, destination. Highlights Sufi concept of perfection, we consider an example of such prominent ideologues of this doctrine, as Ghazali, Farid, Rumi.

Muhammad al-Ghazali (1058-1111) - a thinker reconciled the religion of Islam with intellectualism, influenced Thomas Aquinas, Francis of Assisi and Pascal. He gave answers to the questions posed by the Christian medieval theology to Muslim thinkers, forced to accept the position of Sufism inner meaning of Islam, outlined the contact points of cooperation between intellectualism Dominicans and Franciscans intuitivism, identified rapprochement Muhammadan theology and philosophy of Aristotle.
Sufism, according to Ghazali, is a special kind of activity, the inner teachings of all religions, accessible only to a narrow circle of people who are able to learn. Linking with happiness and perfection perfection, he sought to justify the idea that the improvement requires the transformation of the human mind. The perfect man exists simultaneously in several dimensions, is subject to the object itself and for others. Improvement requires the development of human capabilities, pre-prepare themselves morally in terms of restrictions of pride and overcoming her own efforts. In the process of improving the mind is not distorted and suppressed and transformed, transformed.

For the perception of Sufism as a way of existential, but more mystical experience is necessary to improve the mastery of a particular technology, which means that the practical use of the method, which would allow to neutralize all the negative and at the same time reflect the subject properly, as something objective. The technology is based on symbolization of Sufism, which refers to the ability to higher forms of perception is achieved by conscious effort, for example, the ability to move independently of the body weight, the ability to instantly perception of knowledge as a result of insight or intuition. These attributes of the gas to a higher level of existence. However, it would be wrong to treat gas as a supporter of irrationalism. According to him, a characteristic feature of man is the so-called sixth sense, by which the mind understood Ghazali. In this case, beauty, knowable by reason, majestic beauty comprehended feelings.

Farid al-Din Attar $(1119$ - 1230) in his conception of perfection as the Sufi ideal man, first of all, paid attention to the main task of a man consists in maintaining harmony with all created things. In his monumental work "The Parliament of Birds» Farid proved that various people, including the Sufis, in various stages of development. This idea is expressed by him in figurative, allegorical, symbolic form. Under the guise of a bird hoopoe Sufi collects all of humanity and offers a look mysterious King Semurg the mountain Kaf, but warns that this people have to cross seven valleys.

The first valley is the valley of the search, full of dangers. Here it is necessary to abandon their desires.

Next Valley - Valley of love, such a boundless ocean, where a man obsessed with all the desire to find a lover.

Third Valley - Valley of intuitive knowledge. Here, the heart of man perceives the light of truth and knows God. 
Fourth Valley - Valley of separation, in which a man is freed from desire and dependence.

Fifth Valley - Valley association, where unity is attained earlier seemed different things and ideas.

In the sixth valley - rapture - knowledge is replaced with love. Seventh Valley - Valley of death, in this valley man perceives as a single drop is absorbed by the ocean and, at the same time retains its value.

These valleys are improving the image of the steps, and people often get stuck on any of the steps. Therefore, Sufis are different: some seek knowledge, others turn to God, and others - supporters of love, the fourth - the supporters of unity. The rest are looking for all this, and some below it all. Sufis and have no - or definitions.

King Semurg is the man himself on the path of perfection. But this need to learn to guess. If Socrates said, «Know yourself», that Farid put more difficult task: find yourself repeatedly. And in this repeatedly opened that anyone striving for perfection, and this was Semurg.

If a person is looking for his real way (personally), in the ways of certainty, it will be hidden for the seeker, even though the seeker is the one he is looking for. On the other hand, God will Semurg apparent to a person if he is looking for it in the ways of intuition, mysticism, irrational, mystery. Here Farid gave a distinct advantage mystical method of self-knowledge, which brings him to the position of the views of the famous Western European mysticism as M.Ekhart.

Jalal al-Din Rumi (1207-1273) is recognized in the Eastern tradition as one of the greatest mystics. The most important work of Rumi is «Masnavi-eMaan,» in which he outlined his educational system.

The purpose of the educational system according to Rumi was to help a person achieve harmony with the mystical reality and transform it with this reality. Rumi believed that the Seeker, improving people must first understand themselves as a product standardization with frozen ideas and opinions, automatic response to internal and external impulses, which are formed under the influence of foreign influences. The problem lies in the fact that a person usually think that it is free and has a strong personality. He must abandon the illusion and make an attempt to understand the reality of it for what it really is. At the same time, Rumi believed that, a man prevented the idea from childhood that everything can be understood with the help of logical thinking.

In order to become perfect, or at least strive for excellence, quality must be used, of course inherent in every human being. The most important and the substantial of these qualities is love, which leads a man and humanity to the completeness and, therefore, to perfection. Mankind aware of its incompleteness, resulting in him is born the need to overcome it. It is committed to this, by any means, but just love really contributes to this objective.

The right way of improving the Seeker - active work in the field of public life. Before a person opens the way to improve the work only. Perfection of man, Sufis, should have a good master in any creative profession. However, the work can not be reduced to a simple physical labor, it also means working on ourselves, painstaking spiritual work, by which one attains perfection.

Rumi said that Sufis should pay equal attention to all parts of self. Focusing on one thing leads to a loss of equilibrium. All that man sees and feels, experiences in everyday life is a part of the whole. And the very life of an individual should be considered not only as a separate fragment of life, but also how it all being in general. Therefore, on the path to enlightenment is important to achieve harmony with the whole, i.e. comprehensive work life.

In the process of improving the Sufis enriches their experience and results in their thinking in line with it. Insight, offensive which means achieving a certain degree of perfection, comes gradually.

As a result of insights relevant to everyday life being revised, replaced scholasticism esoteric training. The main thing that motivates a person in this process - the search for truth, which can only be comprehended by means of constant and meticulous work of the spirit. Thus was born a spiritual experience, and people should make great efforts to preserve it, to make its meaning and essence of his being.

Rumi said that the essence of man, the nature of his spiritual life is the struggle of opposites. When these opposites are reconciled, the person becomes perfect, and is beyond the scope of human capabilities, in other words, a person becomes immensely powerful. How this happens, we can only learn from experience, to describe it in words is impossible, said Rumi. At this level of perfection of man acquires a special insight - the correct intuition. Cultivator Sufi becomes able to understand the true meaning of unexplained seemingly events. He has a special insight in all things and more clearly than the average person sees a whole, as part of the whole it is not so interesting.

True Sufi in his actions and deeds will always remember the love of the divine light in the heart. His main rule: «Heart - with God, and hands - at work ...» Scholars and poets Sufis have the broadest 
range of knowledge about the universe, almost all were excellent musicians, astronomers. Among the famous Sufi - Omar Khayyam, Al- Khwarizmi, Rubaie, Jalal ad-Din Rumi, Hafiz, Jami, Nizami, Ibn Arabi and others [4].

According to the teachings of Muslim philosophers of the Middle Ages, excellence in any field can be achieved only if each individual will combine a number of essential virtues, without which he is unable to properly perform the functions assigned to it by society. In the formation of a person of moral and intellectual skills that lead to true happiness, the important role played by education in the humanities, in particular philosophy. Thinkers of the East considered philosophical science as a practical means of human improvement, achieving happiness and salvation of the human race. Happiness, intelligence and virtue is a threefold perfection to which man seeks in life [5]. In order for man to live in harmony with himself, he needs to feel a sense of happiness. Relying on human innate ability to make yourself happy, man is able to achieve happiness through the beautiful action and the same wonderful state of mind, which are made in good faith and on the free choice. Faith in the power and the triumph of the human mind has allowed Al-Farabi assert people in achieving moral and aesthetic ideal is able to improve both independently and in society.

It is known that Al-Farabi in his last years of life lived in Sufi way [6]. As a great scientist and a thinker he created the model of perfect society and perfect man. His concept of perfect society became the base of ideal society, which was considered as utopian idea.

The man is on his way gradually become aware of their moral self-perfection dignity (mind, physical perfection, and so on) and evaluate himself as the supreme and the only principle in the world.

Association of people regarded as spiritual generality of, where people help each other improve their spiritual abilities. Consequently, the civil philosopher reveals the rational principles by which people living in political society, achieve the ultimate goal - happiness, each in accordance with its natural distribution position.

\section{References}

1 Al-Farabi, Talkhis nawamis Aflatun, edited by 'Abd al-Rahman Badawi, in: Aflatan fi l-islam, Beirut, Dar al-Andalus, 1982. - P. 54.

2 Satybekova S.K. Humanism of Al-Farabi. - Alma-Ata, 1975. - P.136-138

3 Al-Farabi. Book of happiness achievement. - Hyderabad, 1926. - P.44-46.

4 Lolita Safronova. Source: http://shkolazhizni.ru/archive/0/n-26980/

5 Zholmuhamedova N. In search of the perfect:Al-Farabi and Ibn Sina. - Almaty, 2014. - P. 181.

6 Derbisaliev A. Aesthetics of Al-Farabi. - Almaty, 1980. - P. 36.

7 Farmer H.G. A history of Arabian music. Goodwords books. - New Delhi, 2002.

8 Eric Voegelin Society Meeting 2009. http://www.lsu.edu/artsci/groups/voegelin/society/2006\%20Papers/Samah\%20Elhajibrahim.shtm

9 Al-Farabi.Treatise on the views of the residents of the virtuous city. - Alma-Ata, 1970. 